\author{
MARTIN BRANIŠ
}

\title{
ENVIRONMENT IN THE CZECH REPUBLIC: STATE OF THE ART AND RECENT DEVELOPMENT UNDER ECONOMIC AND POLITICAL TRANSITION
}

M. B raniš: Environment in the Czech Republic: State of the Art and Recent Development Under Economic and Political Transition. - Geografie-Sborník ČGS, 101, 2, pp. 169 - 179 (1996). - Environmental protection in the Czech Republic has undergone crucial changes since 1989. The initial improvement of environmental quality, however, should be viewed to a great extent as a passive consequence of the inevitable economic restructuring. It is especially the case of chief airborne pollutants that were much reduced since coal mining and the use of fertilizers has been restricted. On the other hand the lower production and use of ozone-destructive chemicals as well as investments into desulphurization of plants are examples of environmental improvements by purpose. The transition towards market economy brings also some negative effects. The amount of municipal waste has risen and public transportation has lost its previous importance. In spite of current positive trends in the environmental protection this branch will require a lot of money. The share of environmental expenses on GDP in the Czech Republic is at the moment two to four times higher than in many EU countries.

KEY WORDS: Czech Republic - environment - economic transition.

\section{Introduction}

The first detailed report on the state of the environment was compiled in 1983 by members of the Czechoslovak Biological Society, Academy of Science (Moldan, B et al., 1983). Since this report confirmed the catastrophic state of natural environment in early 1980s - fears shared by experts and general public - it evoked negative responses within the official Establishment. The stubborn effort of the Communist government to keep pace with the economic development in the West at any expense was the source of evil. Expenses included unlimited exploitation of natural resources, landsacape devastation, deteriorated environment mainly in cities and towns, around giant plants and industrial establishments.

Though many authors of the above mentioned report were oppressed or even prosecuted, five years later the Biological Society again prepared an analysis of the environment in Czechoslovakia (Vavroušek, J., Moldan, B., 1989). The latter report was a detailed one and had much broader scope. It was no longer just a topic of conspiratory discussions among Society members. It was a basis for the complex and respectable publication known as "Blue Book" (Moldan, B., 1990). The Blue Book was among the first documents on the state of the environment readily available to experts, state administration, and the public after 1989. It came into existence sooner than all economic and political analyses and served as a reliable base for constructive environmental activity immediately after the political change of 1989 . 


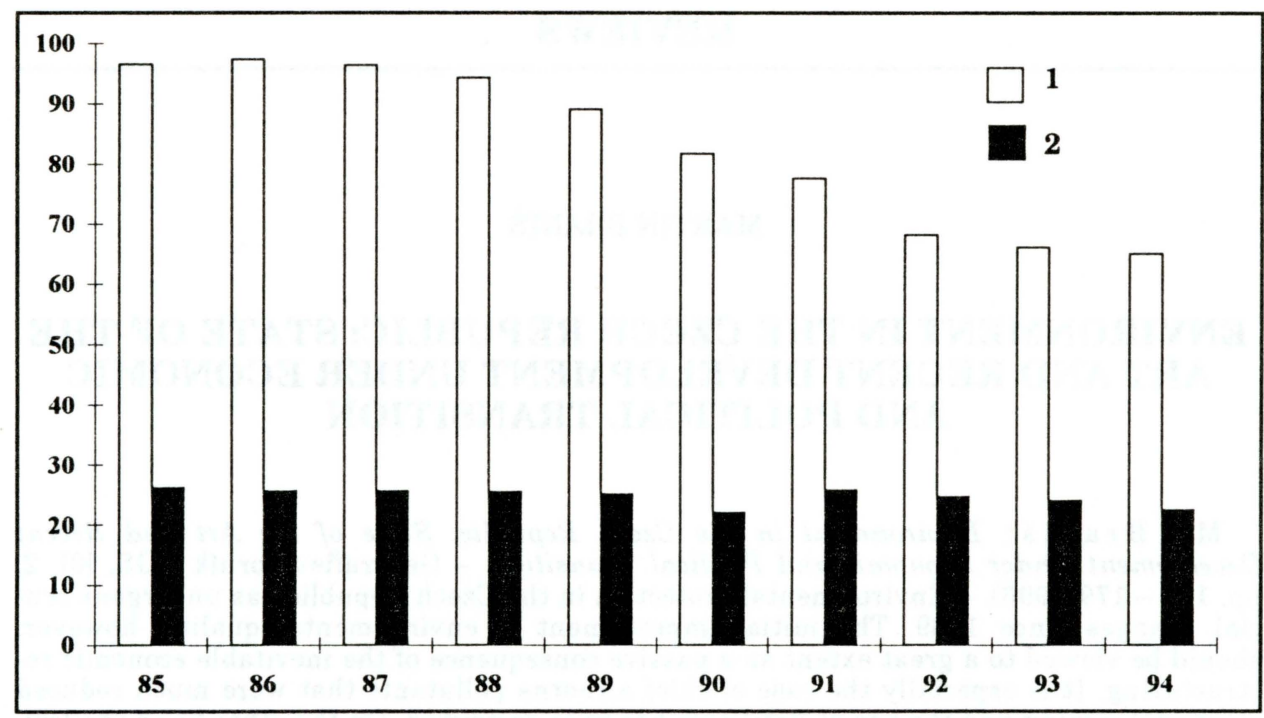

Fig. 1 - Coal Production in the Czech Republic (million of tonnes per year); 1 - brown coal, 2 - black coal

The environmental situation in the Czech Republic at the turn of 1980 s and $1990 \mathrm{~s}$ was a genuine disaster by European standards. The immense amount of coal production (almost 100 million tons per year in the period 1984 - 1987; see Figure 1), exploitation of raw materials and consequent air and water pollution, soil degradation due to heavy agricultural machines and excessive use of fertilizers especially in infertile mountainous areas - all this exceeded reasonable environmental limits. The unsatisfactory state of general health mainly in mining and industrial areas, as well as in big cities, was also perceived as being related to the polluted environment.

"Diagnosis has been identified". For the sake of environmental improvement in the beginning of 1990 there was no urgent need for more environmental experts who would carry out more and more detailed analyses. The monitoring network was also satisfactory. Even raising public awareness did not belong among the chief priorities. Many foreign experts were amazed by the activities of NGOs and by public knowledge about the environment. What really was urgently needed in Czechoslovakia of early 1990 s, however, could not be provided by general public and NGOs: it was the legal and institutional framework for environmental protection and conservation.

\section{Environmental Development Since 1990 - Causes and Trends}

Industrial restructuring, privatization, controlled and sometimes also spontaneous disintegration of huge companies have brought significant - yet often unplanned - environmental improvements. Industrial decline (first of all decrease of heavy industries) and especially decline of brown coal production, stone, sand and gravel mining, and the gradual decrease of uranium industry has resulted in radical decrease of airborne, water, soil, and rock pollution (Figure 2). 


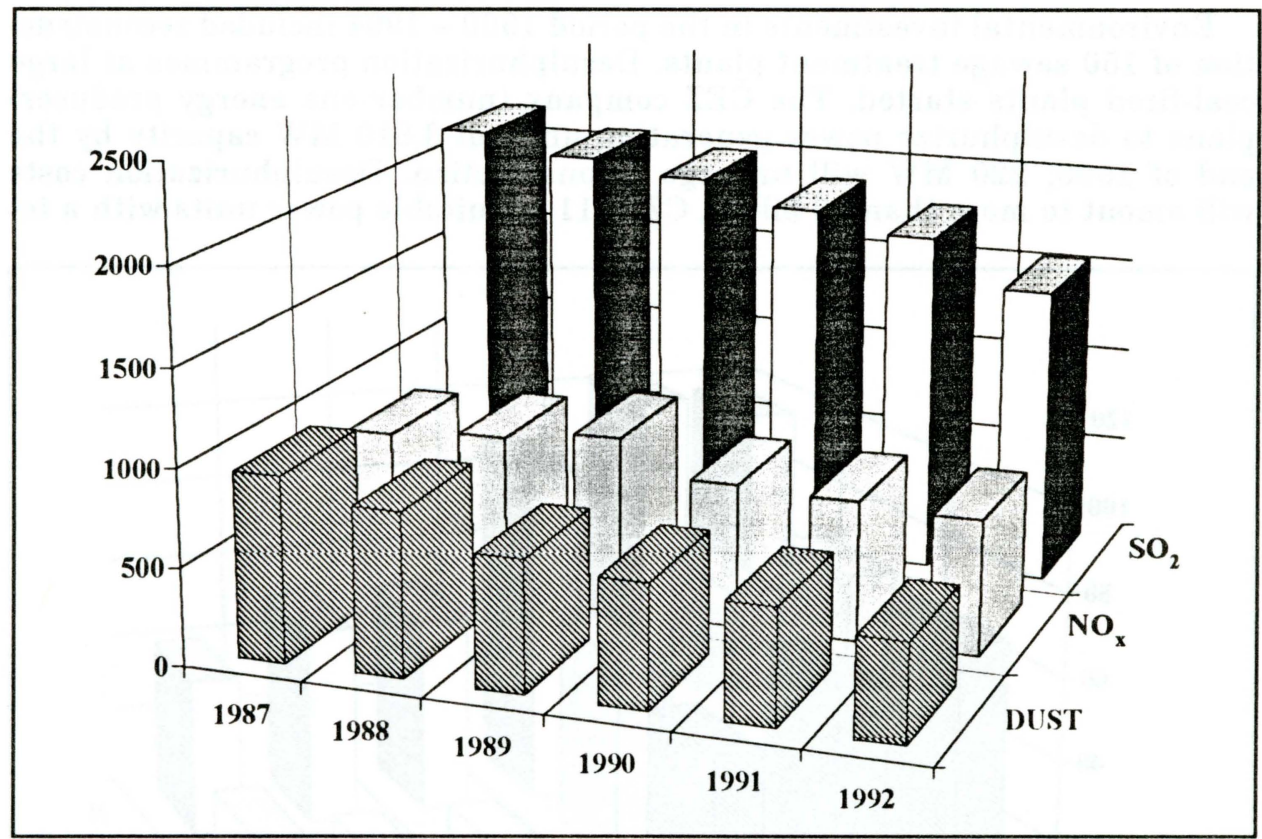

Fig. 2 - Total Emissions of Main Airborne Pollutants in the Czech Republic (thousands of tons per year)

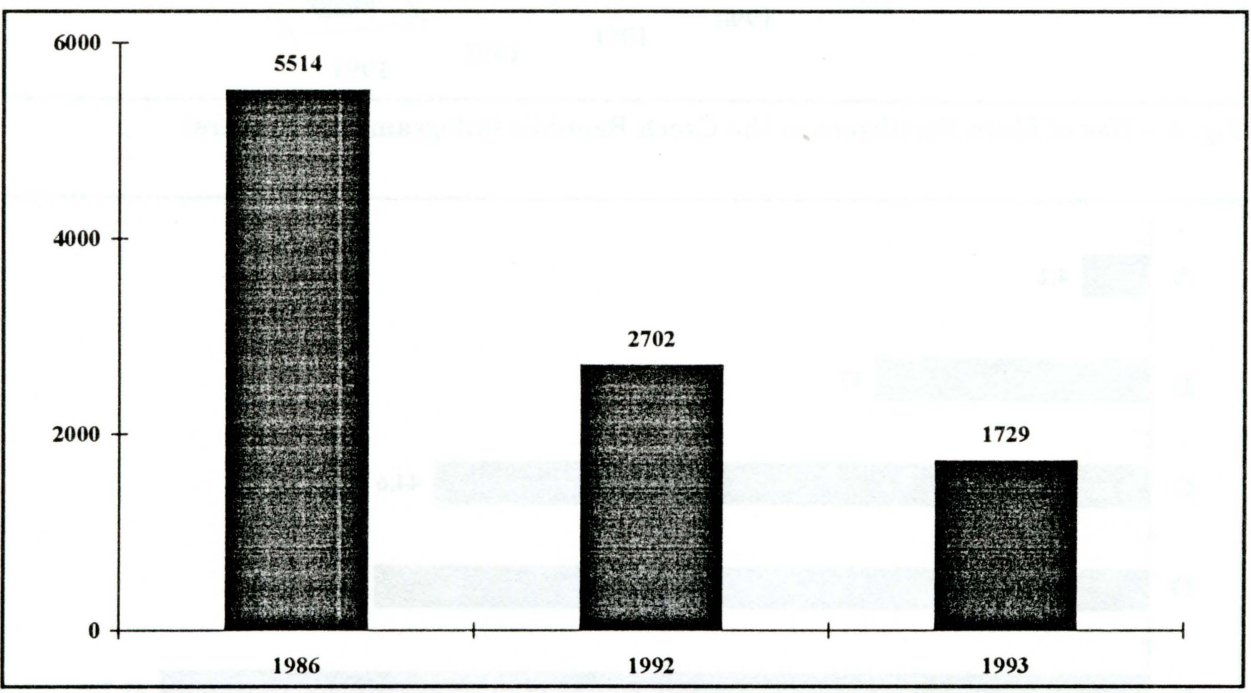

Fig. 3 - Consumption of CFC $(11,12,113$, and 115) in the Czech Republic (tons per year)

Chief airborne pollutants have been reduced by $20 \%$ or even more. Harmless fuels (natural gas) became more frequent and exports of electrical energy declined. Production and consumption of ozone-destructive chemicals has much decreased, too (Figure 3). 
Environmental investments in the period 1990 - 1994 included reconstruction of 150 sewage treatment plants. Desulphurization programmes at large coal-fired plants started. The ČEZ company (number one energy producer) plans to desulphurize power generating units of $3,610 \mathrm{MW}$ capacity by the end of 1996; $220 \mathrm{MW}$ will undergo reconstruction. Desulphurization costs will amout to more than 10 billion CZK. 11 unsuitable power units with a to-

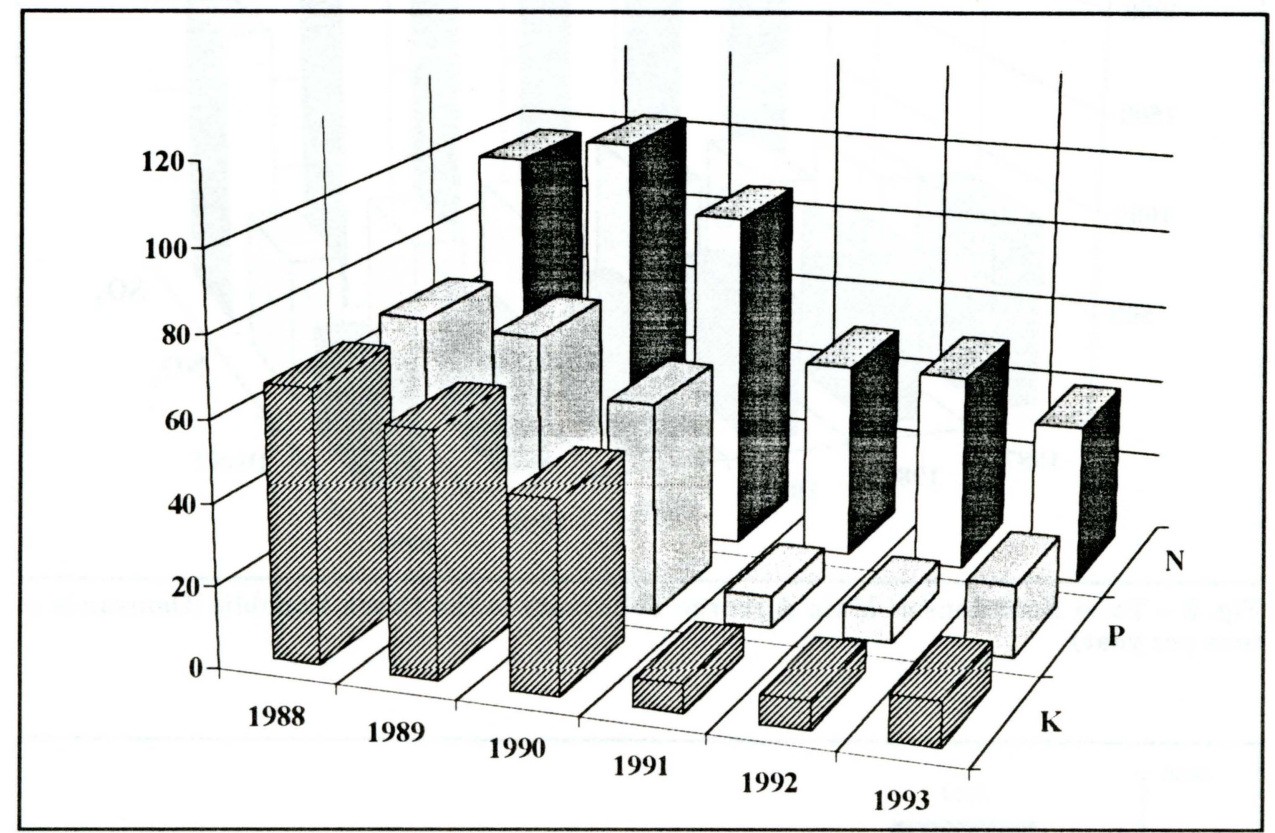

Fig. 4 - Use of Main Fertilizers in the Czech Republic (kilograms per hectare)

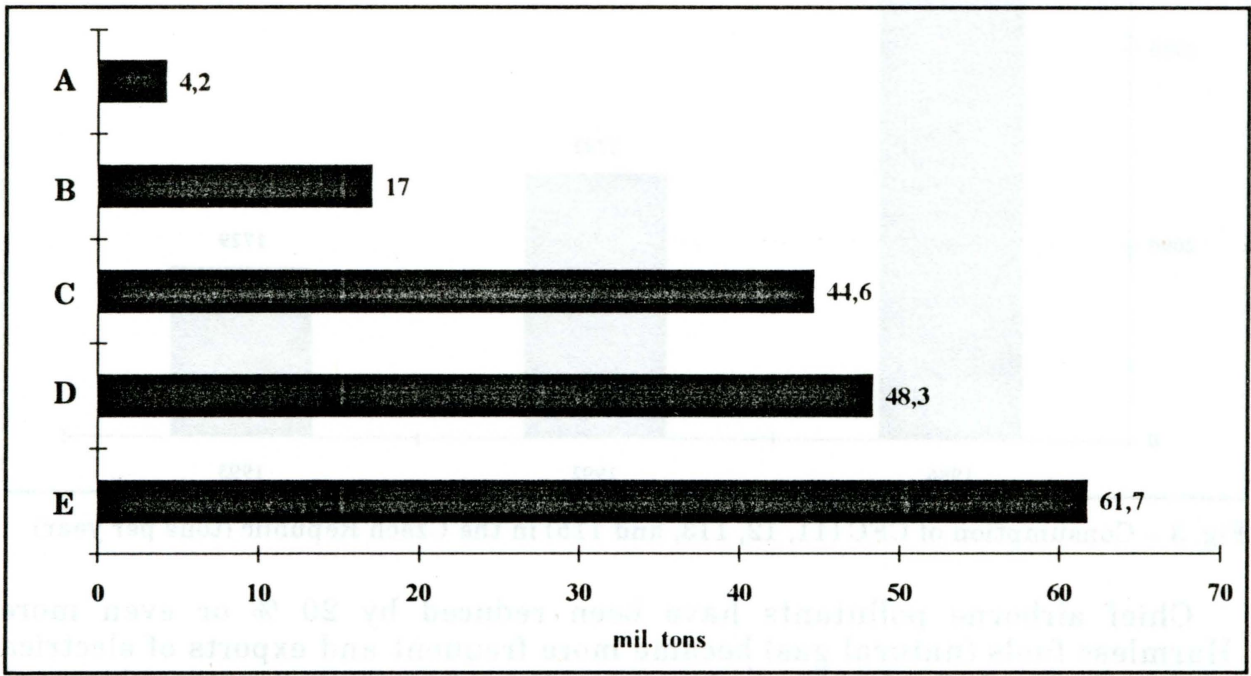

Fig. 5 - Production of Waste in the Czech Republic (OECD classification; total production in 1992 = 187 million tons); $\mathrm{A}$ - municipal, B - energy production, $\mathrm{C}$ - industrial, D - other 


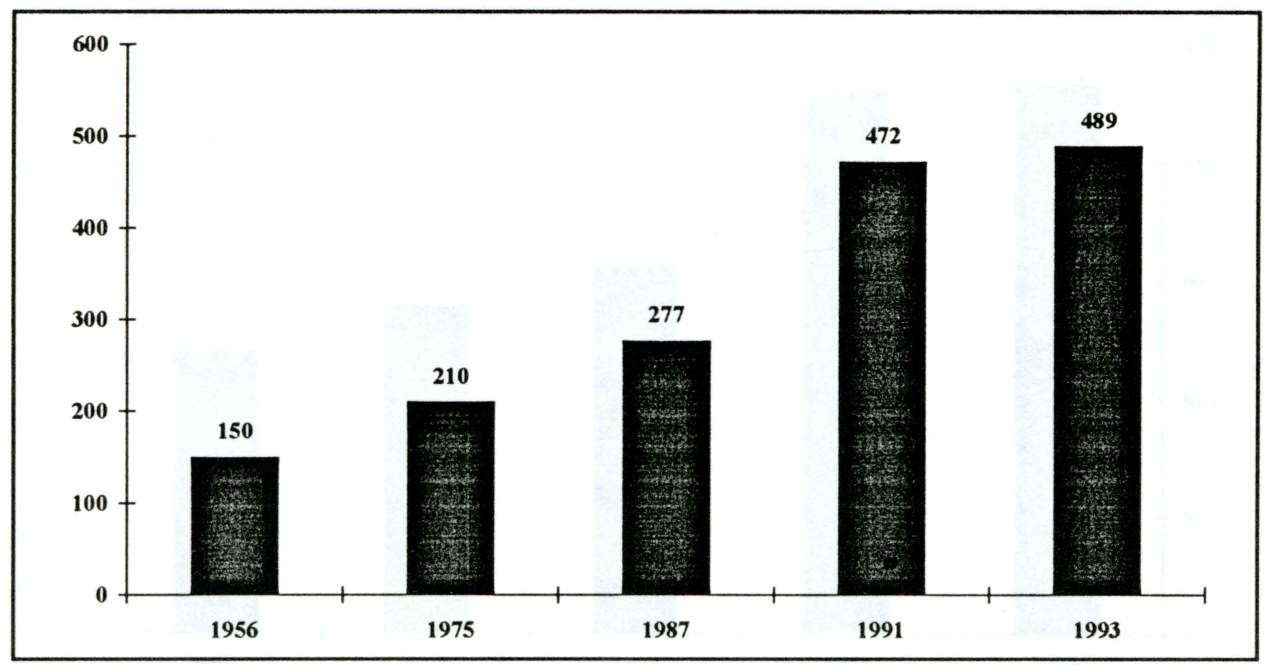

Fig. 6 - Production of Municipal Waste in the Czech Republic (kilograms per capita)

tal capacity of $1,225 \mathrm{MW}$ were closed by the beginning of 1995 and this process continues. Altogether $1,504 \mathrm{MW}$ will come to a halt.

Agricultural production has also declined as the industry did. The extent of arable land has been reduced by $2.5 \%$. This happened mostly in regions with unsuitable climate and poor soils. Some arable land, often of good quality, ceased to exist due to building activities around cities and towns. The use of nitrogenous and phosphoric fertilizers as well as pesticides has declined (Figure 4). These changes, however, can not be viewed as a consequence of planned activities aimed at reducing the environmental load. They were just passive results of cuts in state agricultural subsidies.

No improvements were recorded in the field of waste management (Figure 5). Recent analyses (Ministry of Environment, 1994; Braniš, M., Poncová, M., 1995) have proved that the total waste production does not tend to decrease. The amount of municipal waste has risen tremendously (Figure 6). The investigations of waste production, however, bring unreliable results: neither crude data nor data processing are accurate. (The legal definition of "waste" is vague and to some extent allows manipulation with data.) There were 1,511 dump sites in the Czech Republic in the beginning of 1995; only 280 of them met required standards. Less than 40 incinerators out of 210 conformed to the environmental laws.

Transportation also shows environmentally unfriendly trends. The amount of freight transported on railways has much decreased (Figure 7) and less coal is shipped on the Elbe. On the other hand the intensity and capacity of truck transport has increased. Instead of trains and buses, private cars are used more and more. The number of motor vehicles has been gradually increasing over the period 1991 - 1994 (Figure 8). On the contrary lead emissions have decreased by $75 \%$ since more cars (ca. $8 \%$ of all) have catalytic converters now. The content of lead in gasoline has been much reduced to just $0.15 \mathrm{~g}$ per litre. This figure is comparable to EU countries with the most strict standards (Germany, the Netherlands). ${ }^{1)}$

1) The same legal limit in France is $0.5 \mathrm{~g}$ and in UK $0.4 \mathrm{~g}$ per one litre of leaded gasoline. 


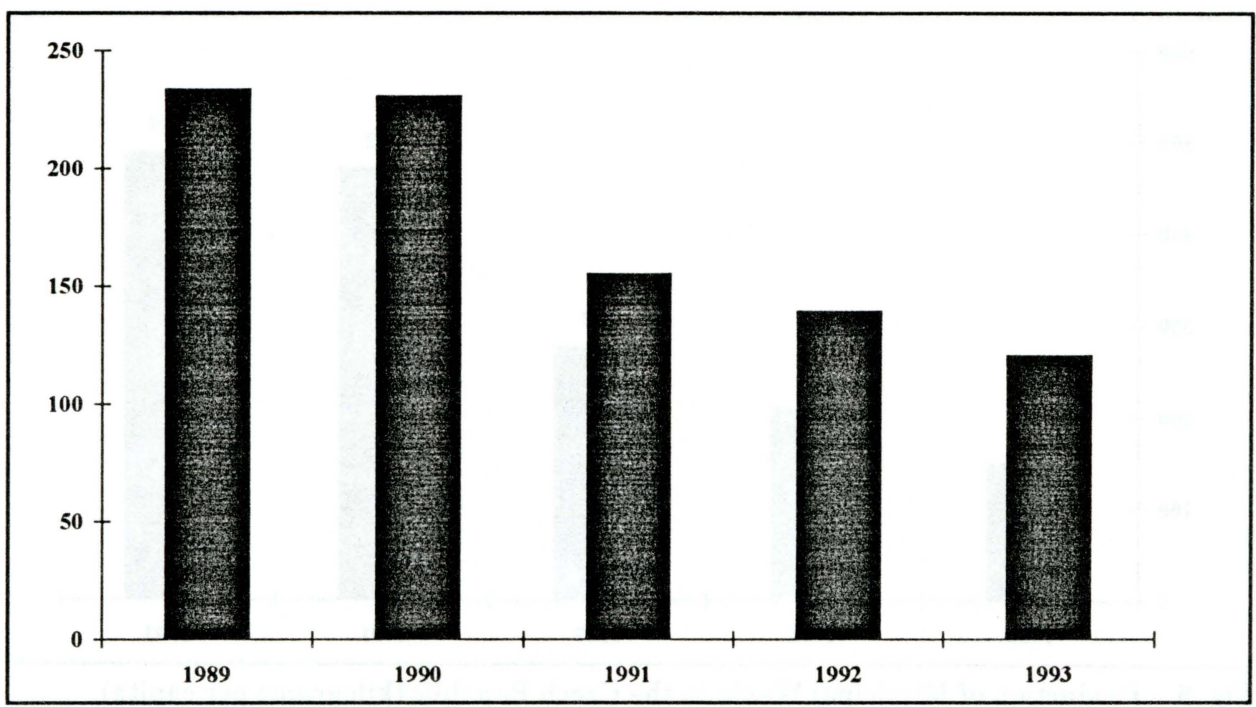

Fig. 7 - Railway Freight in the Czech Republic (million of tons per year)

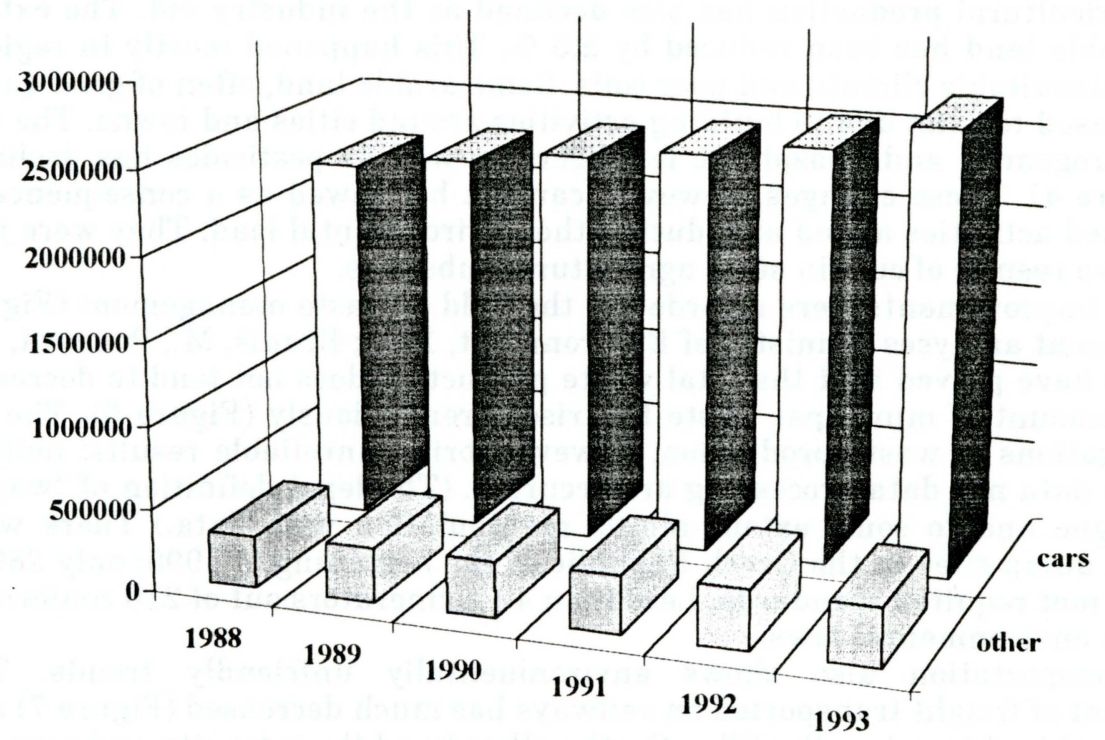

Fig. 8 - Number of Cars and Other Vehicles (vans, lorries, buses, and special vehicles) in the Czech Republic (in million); A - cars, B - other vehicles

The so-called old environmental loads remain a long-term problem that could hardly be found anywhere in Western Europe. The centrally planned economy, namely industry, had almost no legal limits and resulted in longterm environmental pollution and devastation. The former state-owned enterprises were often not forced to conform to the existing laws. As a result loads of toxic chemicals were depositied around factories and plants; the total 
amount has not yet been specified. The presence of Russian occupation troops had similar consequences (especially as regards soil and underground water pollution) as had leaks from landfills. The uranium mining is a special case of an "old" environmental load: in order to obtain uranium ore different acids were injected underground and the uranium solution was subsequently pumped up. 4.4 million tons of sulphuric acid, nitrogenous acid and other chemicals penetrated into the Cenoman uranium strata close to Stráž pod Ralskem (North Bohemia) by 1993. This method of uranium extraction has later been reduced and finally terminated. The devastated area is estimated at ca $30 \mathrm{~km}^{2}$ and 188 million $\mathrm{m}^{3}$ of water is expected to be contaminated.

Decontamination that would remove the old environmental loads is estimated at 10 billions USD. The work will take ca 30 years; decontamination of the uranium district, however, will last 70-100 years. The Czech Government decided to stop the uranium mining by this drastic method on March 6, 1996.

\section{Environmental Laws and Economic Tools}

Passage and enforcement of environmental laws have much contributed to the environmental protection in the Czech Republic. Over 50 environmental laws and decrees of great importance have been approved since 1990! The fundamental law on the environmental protection has been passed and the outdated law on nature and landscape conservation has been thoroughly redone. Laws concerning waste management, air pollution, etc. were also enforced. The essential Environmental Impacts Assessment Act (EIA) has become part of the Czech environmental legal system. Though there are many imperfections in this Act (Braniš, M., Kružíková, E., 1994) it remains an invaluable tool that helps to protect nature, resources, and human health under the current conditons of a building boom and new technological processes.

Controversy, however, has ocurred recently within the Government and Parliament when implementation of more strict environmental standards was discussed. It reflects the clashes between the strong industrial lobby and hard-line environmentalists. Water protection (especially consumption of surface and underground water), forest management (conflict between the economic and non-economic functions of forests), and agricultural land (namely trends encouraging the conversion of agricultural land into building plots, industrial areas, and transportation lines) were among the hot topics. Industrial enterprises have also raised objections against the strict Air Pollution Law that imposes high penalties and fines for production of ozonedestructive chemicals and common harmful substances.

Many environmental laws include charges for releasing dangerous chemicals up to a legal limit and also fines and compensations if these limits are exceeded. Tax reliefs are still unsatisfactory (though some exist) and no taxes have been imposed so far on environmentally hazardous activities (i.e. carbon dioxide tax, energy consumption tax, etc.). Labelling of environmentally friendly products is a sort of economic tool, too, but it lacks better promotion.

\section{Environmental Budget and Finances}

It has been estimated that some $3.5 \%$ of Czech GDP was spent on environmental protection and conservation in 1995 (detailed data are not yet avail- 
Table 1 - Environmental Budget/Expenses in the Czech Republic (million CZK)

\begin{tabular}{|c|c|c|r|r|r|}
\hline Year & State Budget & $\begin{array}{c}\text { State Environmental } \\
\text { Fund }\end{array}$ & $\begin{array}{c}\text { Other } \\
\text { sources }\end{array}$ & Total & \% GDP \\
\hline 1990 & 3,300 & 1,400 & 1,300 & 6,000 & 1.0 \\
1991 & 7,800 & 1,100 & 500 & 9,400 & 1.3 \\
1992 & 10,800 & 1,500 & 4,600 & 16,900 & 2.1 \\
1993 & 8,200 & 3,400 & 8,400 & 20,000 & 2.2 \\
1994 & 8,300 & 3,600 & 16,400 & 28,300 & 2.7 \\
1995 & 8,500 & 4,900 & N.A. & N.A. & 3.5 \\
\hline
\end{tabular}

able). 8.5 billion CZK came from the state budget (Ministry of Environment, 1995); moreover the State Environmental Fund contributed a significant portion, too (Table 1).

The Fund is fed by charges for air pollution (818 million CZK in 1993; 1,587 million CZK in 1995!), waste water release, waste disposal, extraction of underground water, conversion of agricultural land, and extraction of raw materials. Fines imposed on excessive pollution also come to the Fund. The Fund received 4,960 million CZK in 1995 and almost all this money (nearly 4,900 million) was used to support ecological programmes. Both the state budget sources and Fund money are invested into preventive or corrective projects that include extending the natural gas network, sewage plants, drinking water supply, dumps and incinerators, trolley buses, fish programme, vegetation revitalization, research activities, etc. In 1995 the Fund spent $40 \%$ more money than in 1994 and $73 \%$ more compared with 1993 (State Environmental Fund, 1996).

Apart from the above mentioned financial sources environmental projects were also backed by large sums of private money. These were mainly used for direct ecological investments in industrial businesses such as desulphurization, dust reducing programmes, etc. Reduction of the old environmental loads was in case of privatized companies partly financed by the National Property Fund (NPF). The NPF environmental money amounted to 2 billion CZK in 1995. The PHARE subsidies should also be mentioned. PHARE money (ca. 25 million ECU), however, could not be spent on direct investments. This should be changed in the future (Ministry of Environment, 1995).

Measured by the share of GDP the amount of money invested in environmental protection in the Czech Republic seems to be much higher than in other European countries (in 1995 this share was twice as high as in the UK, Germany, and Switzerland). Nevertheless, Czech environmental expenditures should not be cut. The seemingly high share on GDP is counterbalanced by the actual necessity of high environmental investments. Such needs do not exist in EU countries that have been investing into environmental protection ca. $1.5 \%$ of GDP over many decades. The estimated costs for cleaning up the Czech Republic amount to ca 400 billion CZK and it would take 20-30 years. This process, however, should be by no means paid for by state money only. Private firms are expected to contribute a lot and gradual implementation of preventive arrangements should bring results, too. The state money saved could be spent on reducing the "old environmental loads", on reducing the devastating production of uranium ore and coal, and also on implementing environmentally friendly technological processes. 


\section{Social Responses}

A number of environmental groups exists in the Czech Republic. Apart from well-known international ones - e.g. Greenpeace - there are also domestic groups. Some were already active under Communism, others came into existence soon after the political change of 1989. Dozens of environmental educational centres that now play an important role in raising the public awareness have emerged suddenly after 1989. Ecological and environmental issues gradually have become part of education at all levels. Environmental courses are currently lectured at most universities that provide training in natural, technical, social, and medical sciences. A number of environmental textbooks and other sources of knowledge is available. In spite of some imperfections the above mentioned facts must be treated as a real success. Only two university institutes provided environmental courses before 1989 (Braniš, M., 1993). Environmental issues at primary and secondary schools received either very little or no attention at all. Today, environmental knowledge now is part of many existing subjects or even new courses (Braniš, M., 1995). However, nothing like a unified system of environmental education that would include syllabi, methodical suggestions, legal and institutional framework exists in the Czech Republic so far.

One can observe a similar "green boom" also in public media although environmental information is sometimes presented in an unreliable way. The Ministry of Environment should devote more attention to raising the public awareness. This kind of environmental "education" enjoys less interest at the moment than it did between 1989 and 1992.

The current public availability of environmental information and data differs much from the situation under Communism. The Ministry of Environment runs several monitoring systems (air, water, etc.). Data are processed at a regular base, published, and available to everyone. Environmental Yearbooks are released in Czech and English. The 1993/1994 Yearbook already includes OECD and EU standards and criteria and can be used for international comparisons.

\section{Conclusions}

The early 1990 opinion polls revealed that the devastated environment belonged among the most pressing problems. $83 \%$ of questioned Czech citizens in 1990 perceived environmental issues as "one of problems to be discussed by the Government as early as possible" (Moldan, B., 1990). Six years later most of the public interest is devoted to financial affairs, safety, and public security; environment is not any more number one problem. The first post1989 environmental ministers and their staffs successfully raised the public awareness and general interest in environmental problems. Though the current Ministry is often criticized for being weak and having given up environmental concepts in favour of the free market ideas, the Ministry remains an integrated part of the Establishment. This fact should be treated as a positive one even if it is true mainly due to the systematic conceptual, legal, and public activities of the former Federal Committee for Environment and the Czech Ministry of Environment (1990 - 1992).

The Czech Government approved the State Environmental Policy on August 23, 1995 (Ministry of Environment, 1995). This date might be treated as a turning point in the first phase of implementing environmental concepts 
into the society. It also is a result of social stabilization after the post-1989 transition. The proclamation does not include the concept of sustainable development and the relations between economic, energy, and health policies on the one hand and the environmental policy on the other hand is not mentioned. As such it does not fit ideas of hard line environmentalists. Given the fact, however, that the proclamation was approved under conditions of strong pressure from technocratic and market-oriented lobby interested in exploitation of natural sources at any price, it is a success.

\section{References:}

BRADÁČ, J., UNZEITIG, M. (1993): Současný stav sanačních prací na uranovém ložisku Stráž pod Ralskem. In: Reichmann, F. (ed.): Přehled ekologicky zaměřených geologických výzkumných prací v roce 1993. Ministerstvo životního prostředí, Praha, $60 \mathrm{p}$.

BRANIŠ, M. (1993): Environmental Management Curriculum - an Example from the Charles University. In: Environmental Science and Management Studies Yearbook '93 .VIDE Publishers, Riga, $298 \mathrm{p}$.

BRANIŠ, M. (1995): Jak dál v ekologické výchově. Geografické rozhledy, 4, No. 4, Praha, pp. 113-114.

BRANIŠ, M., KRUŽíKOVÁ, E. (1994): The Environmental Impact Assessment Act in the Czech Republic: Origins, Introduction and Implementation Issues. Environ. Impact Assess. Rev. 14, No. 2, pp. 193-199.

BRANIŠ, M., PONCOVÁ, M. (1995): Produkce komunálních odpadů v České republice (manuscript).

MOLDAN, B. (ed.) et al. (1983): Analýza stavu životního prostředí v ČSSR. Ekologická sekce Československé biologické společnosti při ČSAV (manuscript).

MOLDAN, B. (ed.) (1990): Environment of the Czech Republic, Parts I., II., III. Academia, Praha.

MŽP (1994): Environmental Year-book of Czech Republic. Czech Environmental Institute, Praha, $240 \mathrm{p}$.

MŽP (1995): State Environmental Policy (document approved by the government of the Czech Republic on August 23, 1995). Official authorised version of the Ministry of Environment of the Czech Republic.

SFŽP (1996): Hospodaření SFŽP v roce 1995. Informační bulletin SFŽP. Vol. II, No.5, March 1996.

VAVROUŠEK, J., MOLDAN, B. (1989): Stav a vývoj životního prostředí v Československu. Ekologická sekce Československé biologické společnosti při CSAV, 146 p.

\section{Shrnutí}

\section{STAV A VÝVOJ ŽIVOTNÍHO PROSTŘEDÍ ČESKÉ REPUBLIKY V OBDOBÍ EKONOMICKÉ A POLITICKÉ TRANSFORMACE}

Rok 1989 byl v ČR významným předělem nejen pro sféru politickou a hospodářskou, ale také pro oblast zahrnující ochranu životního prostředí. Stav životního prostředí ČR na přelomu 80. a 90 . let byl totiž $\mathrm{v}$ evropských měř́ítkách hodnocen jako katastrofální a občané žádali rychlou kvalitativní změnu. Nadměrná těžba energetického uhlí ( $v$ letech 1984 až 1987 dosahovalo množství vytěženého uhlí téměř $100 \mathrm{mil}$. t/rok, obr. 1), těžba surovin, následné znečištění ovzduší a vody i postupující degradace půdy těžkou technikou a nadměrným používáním strojených hnojiv pro zvýšení fertility málo úrodné půdy $\mathrm{v}$ podhorských oblastech překračovaly meze nosné kapacity prostředí. Do spojitosti se špatným prostř̌edím byl také dáván neuspokojivý zdravotní stav populace, především v těžařských a průmyslových regionech. Hlavním úkolem tehdejší státní administrativy však nebyly další analýzy stavu prostředí, ale spíše příprava a realizace potřebného legislativního a institucionálního rámce pro ochranu životního prostředí. 
V první fázi politické a ekonomické transformace bylo zlepšování stavu dosaženo spíše pasivními cestami. Snížení průmyslové produkce, těžby hnědého energetického uhlí, stavebního kamene, útlum těžby uranu a pokles výroby polotovarů těžkého prủmyslu znamenaly výrazné snížení emisí škodlivých látek do ovzduší, vody i horninového prostředí. Následkem omezení dotací do zemědělství se také výrazně snižila spotřeba dusíkatých a fosforečných hnojiv i pesticidủ.

Zlepšení stavu prostředí však není možno zaznamenat $v$ oblasti produkce odpadů. Celková produkce odpadů od roku 1987 neklesla. Enormní vzrůst je patrný především u komunálního odpadu. K 1.1. 1995 bylo na území České republiky 1511 skládek, z nichž pouze 280 vyhovělo daným předpisům. Z 210 spaloven odpadů necelých 40 splňovalo emisní limity dané zákonem. Environmentálně nepř́íznivá situace se vyvíjí i v sektoru dopravy. Výrazně poklesl objem i tonáž dopravovaného nákladu na železnici, byla omezena doprava energetického uhlí po Labi a zvýšila se nákladní automobilová doprava. Postupně je zaznamenáván stálý nárủst soukromé automobilové dopravy, především na úkor železnice a autobusů.

Stálým a dlouhodobým problémem jsou tzv. staré ekologické zátěže. Jedná se o dlouhodobé poškozování prostředí centrálně plánovanou a velmi málo omezovanou prủmyslovou výrobou (dríve platné zákony nemusely mnohdy státní podniky vủbec respektovat). Podobný dopad na prostředí (především půdu, a podzemní rezervoáry vody) měla i př́tomnost sovětských okupačních armád, prủsaky z nezajištěných a mnohdy nekontrolovaných skládek smíšeného odpadu a také těžba uranu pomocí vtláčení kyselin do podzemí. Do roku 1993, kdy bylo vtláčení výrazně omezeno a následně i zastaveno, bylo v oblasti Stráže pod Ralskem vpraveno do cenomanského ložiska uranu asi 4,4 mil. tun kyseliny sírové, dusičné a dalších chemikálií. V současné době je odhadována plocha postiženého rezervoáru na $30 \mathrm{~km}^{2}$ a množství kontaminované vody na $188 \mathrm{mil} . \mathrm{m}^{3}$.

Zásadním prvkem cílených změn kvality prostředí byla př́íprava a uplatñování řady nových vyhlášek a zákonů. Od roku 1990 bylo postupně uvedeno do praxe více než 50 (!) nových zákonů a vyhlášek zásadního dosahu. Byla připravena základní právní norma o ochraně životního prostředí, zcela byl přepracován již nevyhovující zákon o ochraně přírody a krajiny. V účinnost vešly i zákony o odpadech, ochraně ovzduší a další. Od roku 1992 obsahuje česká environmentální legistativa i zásadní zákon o posuzování vlivů na životní prostředí - EIA. Uplatňování těchto zákonů je možno považovat za hlavní tlak na potenciální znečištovatele životního prostředí.

Zlepšení stavu prostředí lze také přičíst poměrně značnému objemu financí, které jsou do této sféry vkládány. Na ochranu životního prostředí věnovala Česká republika $\mathrm{v}$ roce 1995 okolo 3,5 \% hrubého národního produktu. Kromě státního rozpočtu, který na sféru ochrany životního prostředí přispíval $v$ roce 1995 celkovou částkou 8500 mil. Kč, byl dalším hlavním zdrojem Státní fond životního prostředí (celkem 4960 mil. Kč).

I přes některé přetrvávající problémy je možno označit období prvních 5 let existence svobodného státu (CSFR a pak CR) za období zlepšení stavu prostředí, př́slušné legislativy i respektu $\mathrm{k}$ institucím zabývajících se ochranou životního prostředí. Významným mezníkem pak bylo přijetí oficiální státní ekologické politiky na sklonku roku 1995.

Obr. 1 - Produkce uhlí v České republice. Osa $\mathrm{x}$ - roky, osa y - produkce v mil. tun; 1 hnědé uhlí, 2 - černé uhlí

Obr. 2 - Celkové emise hlavních atmosférických polutantů v České republice (v tis. $\mathrm{t}$ za rok)

Obr. 3 - Spotřeba freonů 11, 12, 113 a 115 v České republice (v tunách)

Obr. 4 - Trendy ve využívání hlavních druhủ hnojiv v České republice (v kg na ha)

Obr. 5 - Produkce odpadů v České republice podle klasifikace OECD (v roce 1992 celkem 187 mil. t); A - komunální, $\mathrm{B}$ - z výroby energie, $\mathrm{C}$ - průmyslové, $\mathrm{D}$ - zemědělské, $\mathrm{E}$ - ostatní

Obr. 6 - Produkce komunálních odpadů v Ceské republice (kg na obyvatele)

Obr. 7 - Železniční doprava v České republice (v mil. tun za rok)

Obr. 8 - Počet osobních automobilů ve srovnání s ostatními druhy vozidel (nákladní automobily, mikrobusy, autobusy, speciální vozidla) v České republice (v milionech); A - osobní automobily, B - ostatní druhy vozidel

(Author is with Institut for Environmental Studies, Faculty of Science, Charles University, Benátská 2, 12801 Praha 2.)

Arrived to the editor's office on March 14, 1996

Recommended for publication by Zdeněk Lipský and Václav Přibyl 